\title{
The Role of Tetrathionate in the Oxidation of Thiosulphate by Chromatium sp. strain D
}

\author{
By A. J. SMITH* \\ Microbiology Unit, Department of Biochemistry, University of Oxford
}

(Received 27 August 1965)

\begin{abstract}
SUMMARY
Sulphate was progressively replaced by tetrathionate as the end product of thiosulphate oxidation by suspensions of Chromatium $D$ when the $\mathrm{pH}$ value was decreased from $7 \cdot 3$ to $6 \cdot 25$; tetrathionate was not itself oxidized to sulphate within this range. The effect of $\mathrm{pH}$ value on the oxidation of endogenous sulphur was less marked than on the production of sulphate from thiosulphate. Extracts of Chromatium D catalysed the oxidation of thiosulphate to tetrathionate in the presence of ferricyanide; $\mathrm{pH} \mathrm{5.0}$ was the optimum of the purified enzyme. Tetrathionate inhibited growth and the complete oxidation of thiosulphate by suspensions. At $\mathrm{pH}$ 6.75 where sulphur accumulated during thiosulphate utilization and sulphate and tetrathionate were formed, added tetrathionate inhibited the accumulation of endogenous sulphur but not the production of tetrathionate from thiosulphate. Tetrathionate had no effect on the oxidation of endogenous sulphur by suspensions. It is concluded that in Chromatium $D$ thiosulphate is metabolized by two alternative pathways depending on the conditions: (1) the cleavage of one molecule of thiosulphate in a reaction similar to that catalysed by thiosulphate sulphur-transferase E.C.2.8.1.1. (rhodanese); (2) the oxidative coupling of two molecules of thiosulphate to give tetrathionate, catalysed by the thiosulphate-oxidizing enzyme which only operates at low $\mathrm{pH}$ values.
\end{abstract}

\section{INTRODUCTION}

Tetrathionate has been suggested as an intermediate in the light-dependent oxidation of thiosulphate to sulphate by purple sulphur bacteria (van Niel, 1936; Eymers \& Wassink, 1937; Wassink, 1941). The evidence, largely indirect, was based on the kinetics of carbon dioxide uptake by suspensions of purple sulphur bacteria in the presence of thiosulphate. In similar studies with Chlorobium thiosulphatophilum which grows on sulphide and thiosulphate but not on tetrathionate, Larsen $(1952,1953)$ reported that tetrathionate was oxidized by suspensions with the concomitant fixation of carbon dioxide. He suggested that tetrathionate might be an intermediate in the oxidation of thiosulphate by this organism. Manometric studies, however, gave no indication of an accumulation of tetrathionate during thiosulphate oxidation.

Tetrathionate not only supports the chemo-autotrophic growth of several species of Thiobacillus, but also accumulates during their growth on other inorganic sulphur compounds (Parker \& Prisk, 1953; Pratt, 1958; Pankhurst, 1964). Several

* Present address: Bacteriology Department, University of California, Berkeley, California, U.S.A. 
workers have reported the accumulation of tetrathionate during the oxidation of sulphur compounds by suspensions of thiobacilli (Vishniac, 1952; Baalsrud \& Baalsrud, 1954; Vishniac \& Santer, 1957; Trudinger, 1959; Jones \& Happold, 1961).

Extracts of Thiobacillus thioparus and T. thio-oxidans have recently been shown to catalyse the oxidation of sulphide, thiosulphate, tetrathionate, trithionate and sulphite to sulphate (Rittenberg \& London, 1964). Tetrathionate was identified as a likely intermediate in the oxidation of sulphide and thiosulphate. Extracts of Thiobacillus $\mathbf{X}$ contain an enzyme which catalyses the oxidation of thiosulphate to tetrathionate (Trudinger, 1958); by using soluble and particulate cytochrome preparations isolated from crude extracts, thiosulphate oxidation has been coupled to the uptake of oxygen. This enzyme is thought to catalyse the initial step in the oxidation of thiosulphate by Thiobacillus.

In the present work, the production of tetrathionate from thiosulphate and the effect of tetrathionate on the complete oxidation of thiosulphate and endogenous sulphur by Chromatium strain $\mathrm{D}$ were investigated to establish the role, if any, of polythionate in the oxidation of thiosulphate to sulphate. Extracts were used to provide an enzymological basis for the observation made with intact organisms.

\section{METHODS}

Organisms, media and growth of cultures. The culture of Chromatium sp. strain D was grown as described by Smith \& Lascelles, (1966). This organism was used throughout these studies except in some experiments with extracts of the Athiorhodaceae Rhodospirillum rubrum and Rhodopseudomonas spheroides. These organisms were grown as described previously (Smith \& Lascelles, 1966).

Preparation and incubation of suspensions. Organisms for suspensions were prepared and incubated as described previously (Smith \& Lascelles, 1966). In the investigation of the effect of $\mathrm{pH}$ value on the oxidation of sulphur compounds, the concentration of sodium bicarbonate was decreased to $3 \mathrm{~mm}$ and the $\mathrm{pH}$ value of the potassium phosphate buffer chosen so as to give the required final $\mathrm{pH}$ value when gassed with $\mathrm{N}_{2} 95 \%(\mathrm{v} / \mathrm{v})+\mathrm{CO}_{2} 5 \%$ (v/v).

Assay of the thiosulphate-oxidizing enzyme. Extracts were prepared as described by Smith \& Lascelles (1966) except that the washed organisms were finally suspended in 0.04 M-potassium phosphate buffer ( $\mathrm{pH} \mathrm{7.5)}$. A modification of the Trudinger (1961) assay was used. The reaction mixture contained, in a volume of $3 \mathrm{ml}$.: acetate buffer ( $\mathrm{pH} \mathrm{5.5}$ ), $350 \mu$ moles; sodium thiosulphate, $25 \mu$ moles; potassium ferricyanide, $7.5 \mu$ moles; enzyme preparation equivalent to $1.5 \mathrm{mg}$. protein of crude extract. The reaction was started by the adding of enzyme. The reference cuvette contained the complete reaction mixture without thiosulphate. Ferricyanide reduction was followed at room temperature (18 to $20^{\circ}$ ) by using a recording double-beam grating spectrophotometer (Optica CF 4DR, Optica U.K. Ltd., Gateshead-on-Tyne, England). The millimolar extinction coefficient of ferricyanide at $418 \mathrm{~m} \mu$ is 1.0 (Ibers \& Davidson, 1951), and a unit of enzyme activity was defined as the amount which catalysed the reduction of $1 \mu$ mole ferricyanide $/ \mathrm{min}$.

Purification of the thiosulphate-oxidizing enzyme. Particle-bound pigment was removed from the extract prepared from 121 . fully grown culture by centrifugation at $100,000 \mathrm{~g}$ for $60 \mathrm{~min}$. in a Spinco model $\mathrm{L}$ ultracentrifuge. The supernatant 
fluid fraction of the extract was treated with $5 \%(w / v)$ streptomycin sulphate (Glaxo Laboratories Ltd., Greenford, England) in 0.04 M-potassium phosphate buffer ( $\mathrm{pH} \mathrm{7.5)}$ to give a final concentration of $1 \mathrm{mg}$. streptomycin sulphate/mg. extract protein. Precipitated nucleic acid was removed after $15 \mathrm{~min}$. by centrifugation at $18,000 \mathrm{~g}$ for $20 \mathrm{~min}$. The supernatant fluid was adjusted to $\mathrm{pH} 4 \cdot 6$ with $\mathrm{N}$-hydrochloric acid and precipitated protein removed after $5 \mathrm{~min}$. by centrifugation at $18,000 \mathrm{~g}$ for $10 \mathrm{~min}$. The supernatant fluid was adjusted to $\mathrm{pH} 7 \cdot 0$ with $\mathrm{N}$-sodium hydroxide. The enzyme was precipitated by $35-55 \%$ of saturation (by volume) with ammonium sulphate. Precipitated protein was removed after $30 \mathrm{~min}$. by centrifugation at $18,000 \mathrm{~g}$ for $20 \mathrm{~min}$. and dissolved in a minimum amount of 0.04 M-potassium phosphate buffer ( $\mathrm{pH} \mathrm{7 \cdot 0)}$. After dialysis for $12 \mathrm{hr}$ against mupotassium phosphate buffer ( $\mathrm{pH} 7 \cdot 0$ ), the concentrated enzyme preparation was applied to a column $(15 \times 1.5 \mathrm{~cm}$.) of DEAE-DE 50 cellulose (Whatman, Colnbrook, England). Protein was eluted with potassium phosphate buffer ( $\mathrm{pH} \mathrm{7.0)}$ by using a concentration gradient (1-200 $\mathrm{mm})$; the flow rate was $1 \mathrm{ml} . / \mathrm{min}$. and the eluate was collected in $5 \mathrm{ml}$. fractions.

Analytical methods. Protein, phosphate, thiosulphate, sulphate and endogenous sulphur were determined as described previously (Smith \& Lascelles, 1966). The amount of tetrathionate in suspensions was determined by the method of Sorbo (1957) in samples of the supernatant medium after the organisms had been removed by centrifugation.

Chromatography of inorganic sulphur compounds. Thiosulphate and polythionates were separated by descending chromatography on Whatman no. 1 paper with the solvent systems described by Skarzynski \& Szczepkowski (1959) and Trudinger (1959). The chromatograms were dried at room temperature and the sulphur compounds located by the method of Trevelyan (1950).

Inorganic sulphur compounds. Sodium salts were used throughout these studies.

\section{RESULTS}

Effect of $p H$ value on growth and the oxidation of inorganic sulphur compounds

Chromatium D grew well on the thiosulphate + salts medium at $\mathrm{pH} \mathbf{7 \cdot 3}$ whereas the organism did not grow on the same medium at $\mathrm{pH} \mathrm{6.5}$. Growth on pyruvate showed a similar dependence on the $\mathrm{pH}$ value of the medium.

Effect of $\mathrm{pH}$ value on the oxidation of thiosulphate. At $\mathrm{pH} 7 \cdot 3$, suspensions of organisms oxidized thiosulphate completely to sulphate under anaerobic conditions in the light in the presence of bicarbonate; there was a transient accumulation of sulphur within the organisms (Fig. 1). At pH 6.25, thiosulphate disappearance was more rapid than at $\mathrm{pH} 7 \cdot 3$ but sulphate production was less than $25 \%$ of the theoretical (Fig. 1) and an accumulation of sulphur within the organisms was not observed. Tetrathionate was found chromatographically in suspensions oxidizing thiosulphate at $\mathrm{pH} \mathrm{6.25}$; there was no trace of polythionate in suspensions oxidizing thiosulphate at $\mathrm{pH} \mathrm{7 \cdot 3}$. The pattern of tetrathionate production in suspensions oxidizing thiosulphate at various $\mathrm{pH}$ values was established by using a quantitative method for determining polythionate (Fig. 1). As the pH value was decreased the amount of tetrathionate produced 
from thiosulphate increased until, at $\mathrm{pH} 6.25$, it was the principal product of thiosulphate utilization. At each $\mathrm{pH}$ value, the sum of tetrathionate+sulphate produced accounted quantitatively for the thiosulphate used by the suspensions.

Tetrathionate, whether produced from thiosulphate by suspensions under acidic conditions (Fig. 1) or added to suspensions in the absence of thiosulphate, was not oxidized to sulphate in the range $\mathrm{pH} \mathbf{7 \cdot 3 - 6 \cdot 2 5}$.

There was no disappearance of thiosulphate or production of polythionates in suspensions of heat-killed organisms or in the absence of organisms between $\mathrm{pH} 7 \cdot 3$ and $\mathrm{pH} 6 \cdot 25$. The lowering of the $\mathrm{pH}$ of suspensions was therefore accompanied by a fundamental change in the pattern of thiosulphate oxidation; sulphur accumulation and sulphate production were progressively replaced by the conversion of thiosulphate to tetrathionate.

Effect of $p H$ on the oxidation of endogenous sulphur. Suspensions of organisms containing considerable amounts of intracellular sulphur oxidized this sulphur to

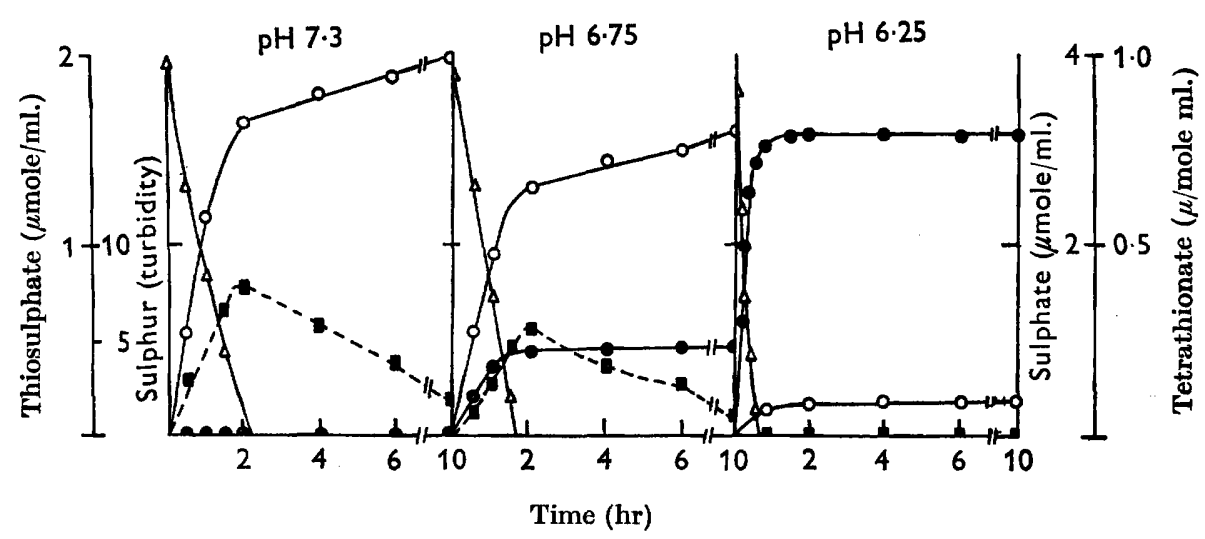

Fig. 1. Effect of $\mathrm{pH}$ value on the oxidation of thiosulphate by suspensions. Suspensions of thiosulphate-grown organisms containing $0.25 \mathrm{mg}$. protein $/ \mathrm{ml}$. were incubated at various $\mathrm{pH}$ values under anaerobic conditions with a light intensity of $500 \mathrm{ft} . c$. in the presence of thiosulphate $(2 \mathrm{~mm})$. Thiosulphate $(-\triangle-)$ disappearance, sulphur $\left(--\square_{-}\right)$and tetrathionate $(-0-)$ accumulation and sulphate $(-\mathrm{O} \rightarrow)$ production were determined.

\section{Table 1. Effect of $p H$ value on the oxidation of endogenous sulphur}

Suspensions of thiosulphate-grown Chromatium D containing intracellular sulphur (equiv. $0.25 \mathrm{mg}$. protein $/ \mathrm{ml}$.) were incubated at various $\mathrm{pH}$ values under anaerobic conditions at a light intensity of $500 \mathrm{ft} . c$. The sulphate produced after incubation for $1 \mathrm{hr}$ and $8 \mathrm{hr}$ was determined. The figures in parentheses refer to sulphate production by suspensions of sulphur-free organisms oxidizing thiosulphate ( $2 \mathrm{~mm}$ ) under similar conditions.

\begin{tabular}{|c|c|c|c|}
\hline \multirow{2}{*}{$\begin{array}{l}\text { Time } \\
(\mathbf{h r})\end{array}$} & \multicolumn{3}{|c|}{ pH } \\
\hline & $7 \cdot 3$ & 6.75 & 6.25 \\
\hline & \multicolumn{3}{|c|}{ Sulphate production $(\mu \mathrm{mole} / \mathrm{hr} / \mathrm{ml}$.) } \\
\hline 1 & $\begin{array}{c}1 \cdot 2 \\
(1 \cdot 5)\end{array}$ & $\begin{array}{c}1.2 \\
(1 \cdot 2)\end{array}$ & $\begin{array}{c}1.2 \\
(0 \cdot 1)\end{array}$ \\
\hline 8 & $\begin{array}{c}3 \cdot 1 \\
(4 \cdot 0)\end{array}$ & $\begin{array}{c}\mathbf{3 \cdot 1} \\
(\mathbf{3} \cdot \mathbf{2})\end{array}$ & $\begin{array}{c}2 \cdot 3 \\
(0 \cdot 4)\end{array}$ \\
\hline
\end{tabular}


sulphate under anaerobic conditions in the light (Smith \& Lascelles, 1966). The effect of $\mathrm{pH}$ value on the oxidation of endogenous sulphur was less marked than its effect on the production of sulphate from thiosulphate (Table 1). Sulphate appeared to be the only product of endogenous sulphur oxidation by suspensions in the range $\mathrm{pH} 7 \cdot 3-6 \cdot 25$.

Tetrathionate production by extracts

Extracts of Chromatium $\mathbf{D}$ catalysed the rapid and complete oxidation of thiosulphate to tetrathionate in the presence of potassium ferricyanide according to the equation

$$
2 \mathrm{~S}_{2} \mathrm{O}_{3}{ }^{2-}+2 \mathrm{Fe}(\mathrm{CN})_{6}{ }^{3-} \rightarrow \mathrm{S}_{4} \mathrm{O}_{6}{ }^{2-}+2 \mathrm{Fe}(\mathrm{CN})_{6}{ }^{4-}
$$

The reaction did not occur with heated extracts.

Properties of the thiosulphate-oxidizing enzyme. The optimum $\mathrm{pH}$ value of the reaction catalysed by crude extracts was below $5 \cdot 5$. The enzyme in crude extracts was insensitive to EDTA $(10 \mathrm{mM})$, fluoride $(10 \mathrm{~mm})$, iodoacetate $(10 \mathrm{~mm})$ and arsenite $(1 \mathrm{~mm})$; azide $(10 \mathrm{~mm})$ decreased the reaction rate by $50 \%$. The Michaelis constant of the enzyme for thiosulphate was $1.5 \mathrm{~mm}$. Extracts did not catalyse the reduction of ferricyanide when thiosulphate was replaced by tetrathionate.

Extracts of Chromatium $\mathbf{D}$ grown on organic carbon had about half the activity of extracts from thiosulphate-grown organisms; the enzyme was not found in extracts of Rhodospirillum rubrum or Rhodopseudomonas spheroides.

\section{Table 2. Purification of the thiosulphate-oxidizing enzyme of Chromatium D}

The details of the individual steps are given in Methods. Five ml. of the dialysed protein fraction were applied to the column of DEAE cellulose.

\begin{tabular}{|c|c|c|c|c|c|}
\hline Stage & Treatment & $\begin{array}{c}\text { Product } \\
\text { volume } \\
\text { (ml.) }\end{array}$ & $\begin{array}{c}\text { Total } \\
\text { protein } \\
\text { (mg.) }\end{array}$ & $\begin{array}{l}\text { Total } \\
\text { enzyme } \\
\text { (units) }\end{array}$ & $\begin{array}{c}\text { Specific } \\
\text { activity } \\
\text { (units/mg. } \\
\text { protein) }\end{array}$ \\
\hline $\mathbf{I}$ & French press & 27 & 1350 & 1000 & 0.7 \\
\hline II & High-speed centrifugation & 22 & 572 & 853 & 1.5 \\
\hline III & Streptomycin sulphate & 24 & 480 & 804 & $1 \cdot 7$ \\
\hline IV & Acid precipitation & $\mathbf{2 4}$ & 209 & 670 & $3 \cdot 2$ \\
\hline $\mathbf{V}$ & $\begin{array}{l}\text { Ammonium sulphate } \\
\text { (35-55 \% saturation) }\end{array}$ & $5 \cdot 2$ & 85 & 624 & $7 \cdot 3$ \\
\hline VI & Dialysis & $6 \cdot 6$ & 85 & 521 & $6 \cdot 1$ \\
\hline \multicolumn{6}{|c|}{ (Fractions 15-19) } \\
\hline VII & $\begin{array}{l}\text { Chromatography on DEAE } \\
\text { cellulose }\end{array}$ & $\mathbf{2 5}$ & $3 \cdot 2$ & 253 & 79 \\
\hline
\end{tabular}

Purification of thiosulphate-oxidizing enzyme. The enzyme from extracts of thiosulphate-grown Chromatium D was partially purified in a seven stage process (Table 2) which involved column chromatography on DEAE cellulose. The thiosulphate-cleaving and thiosulphate-oxidizing enzymes were completely separated on the column of substituted cellulose (Fig. 2). The reaction catalysed by the 100-fold purified enzyme was optimumal at pH 5.0 (Fig. 3). 
Effect of tetrathionate on the oxidation of inorganic sulphur compounds

Tetrathionate did not support the growth of Chromatium D under autotrophic conditions and it inhibited the growth of the organism on the thiosulphatesalts medium as well as on organic media (Smith \& Lascelles, 1966). Thiosulphate utilization and sulphur accumulation by suspensions at $\mathrm{pH} \mathbf{7 \cdot 3}$ were inhibited by

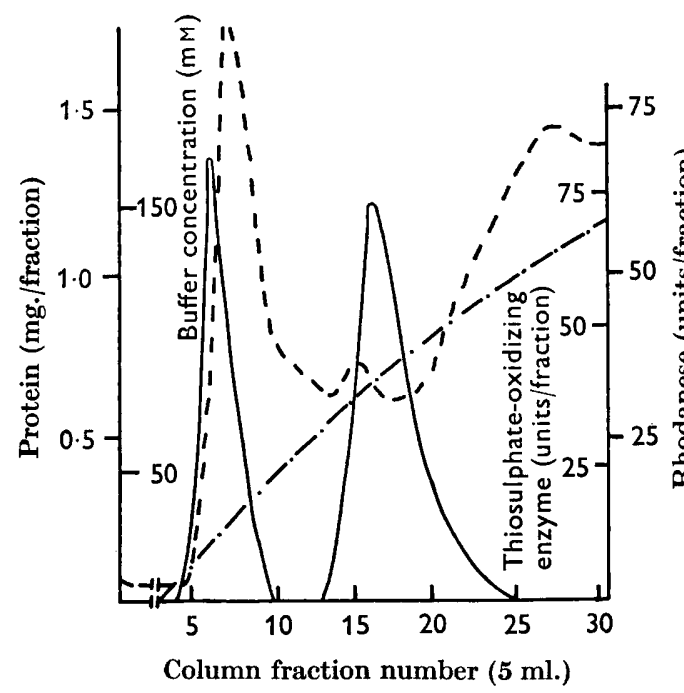

Fig. 2

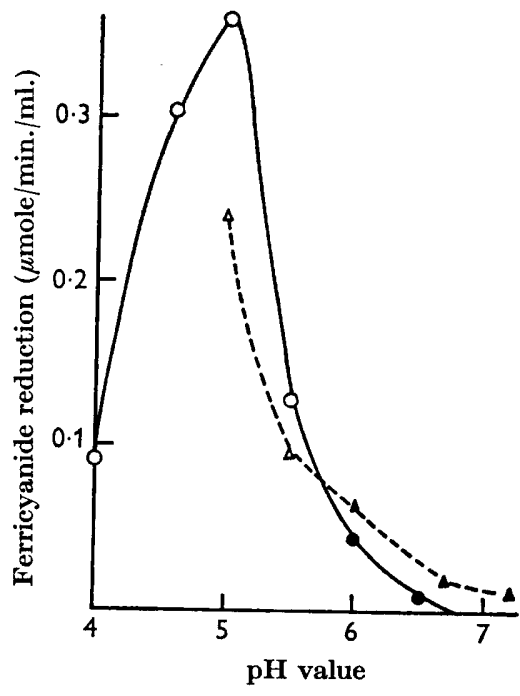

Fig. 3

Fig. 2. Chromatography of the thiosulphate-oxidizing enzyme on DEAE cellulose. The protein fraction from stage VI was applied to a column of DEAE-DE 50 cellulose. The thiosulphate-oxidizing enzyme was eluted with 75-90 $\mathrm{mm}$ buffer (column fractions 15-19) whilst rhodanese was eluted from the column with 10-35 mM buffer (column fractions 5-9). Protein (- - ), enzyme activity (-), and buffer concentration $(-\cdot-\cdot-)$ were determined.

Fig. 3. Optimum pH value of the thiosulphate-oxidizing enzyme. Phosphate (full symbols) and acetate (open symbols) buffers of the appropriate $\mathrm{pH}$ were used in the determination of the activity of the enzyme in a crude extract (- - - ) and in a purified preparation (-) from the DEAE cellulose column. Protein was precipitated from reaction mixtures containing crude extract below $\mathbf{p H} 5 \cdot 5$.

\section{Table 3. Effect of tetrathionate on thiosulphate utilization and sulphur accumulation by Chromatium $\mathrm{D}$ at $\mathrm{pH} \% \cdot 3$ and $6 \cdot 25$}

Suspensions of thiosulphate-grown Chromatium D (equiv. 0.25 mg. protein/ml.) at pH $7 \cdot 3$ or pH 6.25 were incubated at a light intensity of $500 \mathrm{ft}$.c. under anaerobic conditions with thiosulphate $(5 \mathrm{~mm})$ and various concentrations of tetrathionate.

$\begin{array}{cccc}\text { Tetrathionate } & \begin{array}{c}\text { Thiosulphate } \\ \text { concentration } \\ (\mu \text { moles } / \text { ml. })\end{array} & \begin{array}{c}\text { Sulphur accumulation } \\ \text { (maximum turbidity } \\ (\mu \text { moles } / \mathrm{hr} / \mathrm{ml} .)\end{array} & \begin{array}{c}\text { change) } \\ \text { pH }\end{array} \\ 7 \cdot 3 & 0 & 2 \cdot 7 & 12 \cdot 8 \\ & 2 \cdot 5 & 0 \cdot 6 & 2 \cdot 8 \\ 6 \cdot 25 & 5 & 0 \cdot 3 & 0 \cdot 9 \\ & 0 & 4 \cdot 8 & 0 \\ & 2 \cdot 5 & 4 \cdot 6 & 0 \\ & 5 & 4 \cdot 2 & 0\end{array}$


tetrathionate (Table 3); the inhibition was non-competitive and reversed by washing. The effect of tetrathionate on thiosulphate disappearance was much less at $\mathrm{pH} \mathrm{6.25}$ than at $\mathrm{pH} \mathbf{7 \cdot 3}$ (Table 3). At the intermediate value $\mathrm{pH} \mathrm{6.75}$, where sulphur accumulated transiently and sulphate and tetrathionate were the products of thiosulphate oxidation, sulphur accumulation was markedly inhibited by added tetrathionate, whereas tetrathionate production from thiosulphate was, if anything, increased (Fig. 4). Added tetrathionate had no effect on the oxidation of endogenous sulphur by suspensions. Tetrathionate reacts spontaneously with sulphide and sulphite and this prevented a study of its effect on the oxidation of these compounds.
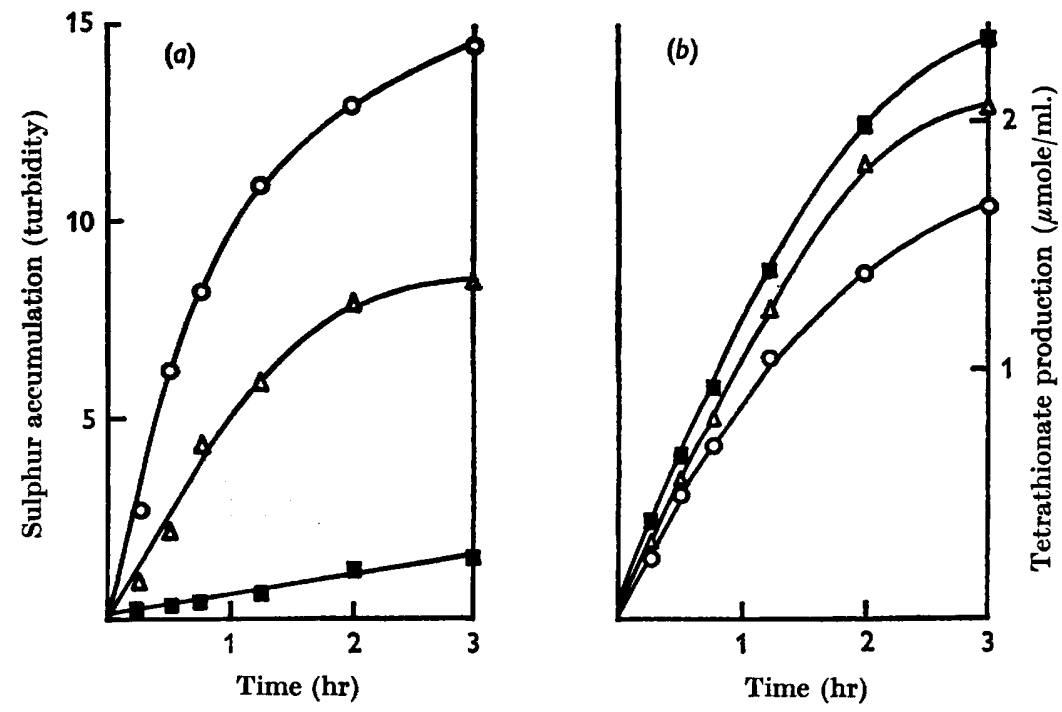

Fig. 4. Differential effect of added tetrathionate on the accumulation of sulphur (a) and tetrathionate $(b)$ at pH 6.75. Suspensions of thiosulphate-grown organisms containing $0.2 \mathrm{mg}$. protein/ml. were incubated anaerobically in the light at pH 6.75 in the presence of thiosulphate $(6 \mathrm{~mm})$ and various concentrations of tetrathionate: $10 \mathrm{~mm}$ $(-\square-), 1 \mathrm{~mm}(-\triangle-)$ and none $(-\mathrm{O}-)$.

\section{DISCUSSION}

Chromatium D unlike Thiobacillus thio-oxidans did not grow on inorganic media at pH 6.5. Nevertheless, suspensions of Chromatium D utilized thiosulphate at $\mathrm{pH}$ values below 6.5. Sulphur accumulation and sulphate production were, however, greatly decreased at $\mathrm{pH} \mathrm{6.25}$; the yield of sulphate under these conditions was less than $25 \%$ of the theoretical. Tetrathionate was the principal product of thiosulphate utilization at $\mathrm{pH}$ 6.25 whereas at $\mathrm{pH} \mathbf{7 \cdot 3}$ there was no detectable accumulation of tetrathionate during thiosulphate oxidation. Two possible explanations of the accumulation of tetrathionate at acid $\mathrm{pH}$ values were: (1) the accumulation of tetrathionate, a possible intermediate in thiosulphate oxidation, was due to the inactivity at acid pH of the enzymes for its further oxidation; (2) tetrathionate was the product of an enzyme reaction which was only functional at low $\mathrm{pH}$ values. The fact that tetrathionate was not oxidized in the range $7 \cdot 3-$ 6.25 favoured the second explanation. 
Extracts of Chromatium D contained a soluble enzyme distinct from rhodanese which catalysed the oxidation of thiosulphate to tetrathionate. Such an enzyme was described by Trudinger (1958) in extracts from Thiobacillus strain $x$. The enzyme in crude extracts of Chromatium $\mathrm{D}$ was only slightly active at $\mathrm{pH} \mathbf{7 \cdot 0}$; the purified enzyme had an optimum at $\mathrm{pH} \mathrm{5.0.} \mathrm{In} \mathrm{view} \mathrm{of} \mathrm{its} \mathrm{properties} \mathrm{it} \mathrm{is} \mathrm{likely} \mathrm{that} \mathrm{this}$ enzyme is involved in the production of tetrathionate from thiosulphate by intact organisms at low $\mathrm{pH}$ values.

The inhibition by tetrathionate of thiosulphate utilization and of sulphur accumulation at $\mathbf{p H ~} \mathbf{7 \cdot 3}$ was an additional complicating factor. At the intermediate value $\mathrm{pH} \mathrm{6.75}$, where both sulphate and tetrathionate were products of thiosulphate oxidation, added tetrathionate inhibited the intracellular accumulation of sulphur but did not affect the production of tetrathionate from thiosulphate.

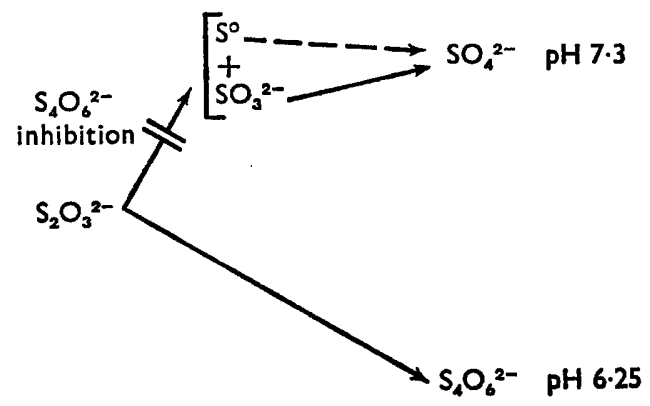

Fig. 5. The oxidation of thiosulphate by Chromatium D.

In contrast, tetrathionate had no effect on the oxidation of endogenous sulphur. The site of the inhibition of the conversion of thiosulphate to sulphate was therefore likely to be at a stage before the oxidation of endogenous sulphur. The results of this and other work (Smith \& Lascelles, 1966) suggested that thiosulphate was metabolized by the two mechanisms outlined in the scheme shown in Fig. 5, one catalysed by a rhodanese-like enzyme and the other by the thiosulphateoxidizing enzyme.

Wassink, Katz \& Dorrestein (1941) investigated the fixation of carbon dioxide by suspensions of a species of Chromatium and found it to be most rapid at $\mathrm{pH} 6 \cdot 3$ in the presence of excess thiosulphate. At this $\mathrm{pH}$ value carbon dioxide fixation was accompanied by the production of alkali (measured by chemical binding of carbon dioxide) which was attributed to the conversion of thiosulphate to tetrathionate. On this basis, tetrathionate was proposed as an intermediate in thiosulphate oxidation. In the present work direct analysis for thiosulphate and its oxidation products has shown that lowering from $\mathrm{pH} 7.3$ to 6.25 resulted in a fundamental change in the reactions for the oxidation of thiosulphate in which sulphate was replaced by tetrathionate as the end-product of oxidation. Wassink (1941) correctly interpreted the results of his experiments at $\mathrm{pH} \mathrm{6.3} \mathrm{in} \mathrm{terms} \mathrm{of} \mathrm{the}$ oxidation of thiosulphate to tetrathionate; his investigation, based only on measurement of carbon dioxide fixation, did not however reveal the change in the pattern of thiosulphate oxidation which accompanied the change in $\mathrm{pH}$. Since 
fixation of carbon dioxide can apparently be coupled to the conversion of thiosulphate to tetrathionate at a $\mathrm{pH}$ value where growth is not possible, this oxidation process might be of some importance to the organism. The change from sulphate to tetrathionate production at acid $\mathrm{pH}$ values would be beneficial to an organism oxidizing thiosulphate in that acidic products would be replaced by the production of alkali: (1) complete oxidation: $\mathrm{Na}_{2} \mathrm{~S}_{2} \mathrm{O}_{3} \rightarrow \mathrm{Na}_{2} \mathrm{SO}_{4}+\mathrm{H}_{2} \mathrm{SO}_{4} ;$ (2) incomplete oxidation: $2 \mathrm{Na}_{2} \mathrm{~S}_{2} \mathrm{O}_{3} \rightarrow \mathrm{Na}_{2} \mathrm{~S}_{4} \mathrm{O}_{6}+2 \mathrm{NaOH}$.

The inhibition of the complete oxidation of thiosulphate by tetrathionate would also prevent the further production of acidic oxidation products, whilst permitting the assimilation of carbon dioxide coupled to the oxidation of thiosulphate to tetrathionate.

The author wishes to thank Dr June Lascelles for advice and encouragement during this work and the Agricultural Research Council for a postgraduate Research Studentship.

\section{REFERENCES}

BaAlsrud, K. \& BaAlsrud, K. S. (1954). Studies on Thiobacillus denitrificans. Arch. Mikrobiol. 20, 34.

Eymers, J. G. \& WAssink, E. C. (1937). On the photochemical carbon dioxide assimilation in purple sulphur bacteria. Enzymologia, 2, 258.

Ibers, J. A. \& Davidson, N. (1951). On the interaction between hexacyanatoferrate (III) ions and (a) hexacyanatoferrate (II) or (b) iron (III) ions. J. Amer. chem. Soc. 73, 476.

Jones, G. L. \& HAPPoID, F. C. (1961). The occurrence of polythionates as intermediates in the metabolism of thiosulphate by the thiobacilli. J. gen. Microbiol. 26, 361 .

LARSEN, H. (1952). On the culture and general physiology of the green sulphur bacteria. J. Bact. 64, 187.

LARSEN, H. (1953). On the microbiology and biochemistry of the photosynthetic green sulphur bacteria. K. norske Vidensk. Selsk. Skr. NR1.

van NIEI, C. B. (1936). On the metabolism of the Thiorhodaceae. Arch. Mikrobiol. 7, 323.

Pankhurst, E. S. (1964). Polarographic evidence of the production of polythionates during the bacterial oxidation of thiosulphate. J. gen. Microbiol. 34, 427.

Parker, C. D. \& Prisk, J. (1953). The oxidation of inorganic compounds of sulphur by various sulphur bacteria. J. gen. Microbiol. 8, 344.

Prate, D. P. (1958). Detection of polythionates in cultures of thiobacilli by means of the Folin-Ciocalteu reagent. Nature, Lond. 181, 1075.

Rittenberg, S. C. \& London, J. (1964). Path of sulphur in sulphide and thiosulphate oxidation by thiobacilli. Proc. natn. Acad. Sci., U.S.A. 52, 1183.

SkarzYNSKI, B. \& Szczeprowski, T. W. (1959). Oxidation of thiosulphate by Thiobacillus thioparus. Nature, Lond. 183, 1413.

Smith, A. J. \& Lascelles, J. (1966). Thiosulphate metabolism and rhodanese in Chromatium sp. strain D. J. gen. Microbiol. 42.

SorBo, B. (1957). A, colorimetric method for the determination of thiosulphate. Biochim. biophys. Acta 23, 412.

Trevelyan, W. B. (1950). Detection of sugars on paper chromatograms. Nature, Lond. $166,444$.

Trudinger, P. A. (1958). Cytochromes and thiosulphate oxidation in an aerobic Thiobacillus. Biochim. biophys. Acta, 30, 211.

Trudinger, P. A. (1959). The initial products of thiosulphate oxidation by Thiobacillus x. Biochim. biophys. Acta, 31, 270. 
Trudinger, P. A. (1961). Thiosulphate oxidation and cytochromes in Thiobacillus X. 2. Thiosulphate-oxidizing enzyme. Biochem. J. 78, 680 .

Vishniac, W. (1952). The metabolism of Thiobacillus thioparus. 1. The oxidation of thiosulphate. J. Bact. 64, 363.

Vishniac, W. \& Santer, M. (1957). The Thiobacilli. Bact. Rev. 21, 195.

WASsink, E. C. (1941). On the ratio between the uptake of carbon dioxide and of the hydrogen donor in purple sulphur bacteria. Enzymologia, 10, 257.

Wassink, E. C., Katz, E. \& Dorrestein, R. (1941). On the photosynthesis and fluorescence of bacteriochlorophyll in Thiorhodaceae. Enzymologia, 10, 285. 